\title{
Isolation of Yeast Ascospores Free of Vegetative Cell Contamination
}

\author{
By AMITAVA CHATTERJEE, SHYAMALI GHOSH, SAMPA DAS \\ AND S. K. SEN* \\ Programme in Genetical Research, Botany Department, Bose Institute, Calcutta 700 009, India
}

(Received 10 August 1981; revised 24 February 1982)

\begin{abstract}
A method has been devised for isolating yeast ascospores and asci free from vegetative cell contamination. By careful manipulation of the size and surface properties of the spheroplasted vegetative cells and asci, a pure preparation of ascospores could be recovered by sucrose gradient centrifugation.
\end{abstract}

\section{INTRODUCTION}

The advantages of sporulating diploid yeast (Saccharomyces cerevisiae) for meiotic studies have been realized by a number of workers (Roth \& Fogel, 1971; Simchen et al., 1972; Pinon et al., 1974; Esposito \& Esposito, 1974; Shilo et al., 1978). Unfortunately, yeast cells respond asynchronously to the sporulation stimulus in acetate-containing growth medium. Consequently, it has been difficult to analyse the meiotic developmental programme. However, characterization of developmental stages, such as readiness and commitment to meiosis has been achieved (Simchen et al., 1972) by monitoring the first batch of meiotic products (asci) formed. To extend this approach, it is necessary to use the first batch of asci to monitor the features of the developmental phases of meiosis. However, suitable techniques for isolating the first batch of asci from the remaining cells were not available. Thus, it was necessary to devise a technique for isolating the first asci formed, which are quite small in size, free from any contamination by vegetative cells. Previously described techniques for spore isolation (Resnick et al., 1967; Tingle et al., 1974; Dawes \& Hardie, 1974; Padilla et al., 1975; Betz \& Weiser, 1976; Nishi et al., 1978; Dawes et al., 1980) fell short of this requirement. The separation technique of Dawes et al. (1980) was considered; however, it was felt that the technique did not yield fractionation of exclusively asci/ascospores. By exploiting differences in surface properties and size of spheroplasted vegetative cells and asci of yeast a simple but effective technique has been devised.

\section{METHODS}

The diploid strain 131 (obtained from Professor G. Simchen, Jerusalem) was used, growth and sporulation conditions were those of Simchen et al. (1972) in which at $30^{\circ} \mathrm{C}$ the onset of ascus formation took place at the 11 th hour of sporulation. Harvesting of cells for the present study was carried out after $12 \mathrm{~h}$.

Preparation of yeast spheroplasts. Spheroplasting of the yeast cells was by a similar method to that of Klein \& Byers (1978). Cells were incubated for $30 \mathrm{~min}$ in $0.1 \mathrm{M}$-mercaptoethanol containing $0.2 \mathrm{M}$-Tris and 0.02 M-EDTA. They were then transferred to $1 \mathrm{M}$-sorbitol, $0.02 \mathrm{M}$-sodium citrate/phosphate buffer (pH 5.9), containing $0.01 \mathrm{M}$ EDTA with $8 \mathrm{mg}$ Helicase $\mathrm{ml}^{-1}$ (Pharmindustrie, Clichy). Incubation of the yeast cells was carried out for $2 \mathrm{~h}$ at $37^{\circ} \mathrm{C}$. All operations were carried out aseptically. Spheroplasts and other fractions were examined by phase contrast microscopy.

Viability test. Samples containing asci/ascospores were counted using a haemocytometer. After suitable dilution, they were plated on YEPD medium $(1 \%, \mathrm{w} / \mathrm{v}$ yeast extract $; 2 \%, \mathrm{w} / \mathrm{v}$ peptone $; 2 \%$, w/v glucose, and $2 \%$, w/v agar) and incubated for $3 \mathrm{~d}$ at $30^{\circ} \mathrm{C}$. Colony counts were made to determine the viability.

\section{RESULTS AND DISCUSSION}

Our efforts have been directed towards isolating asci and ascospores intact and free from vegetative cell contamination from a heterogeneous mixture containing about $5 \%$ asci. The 

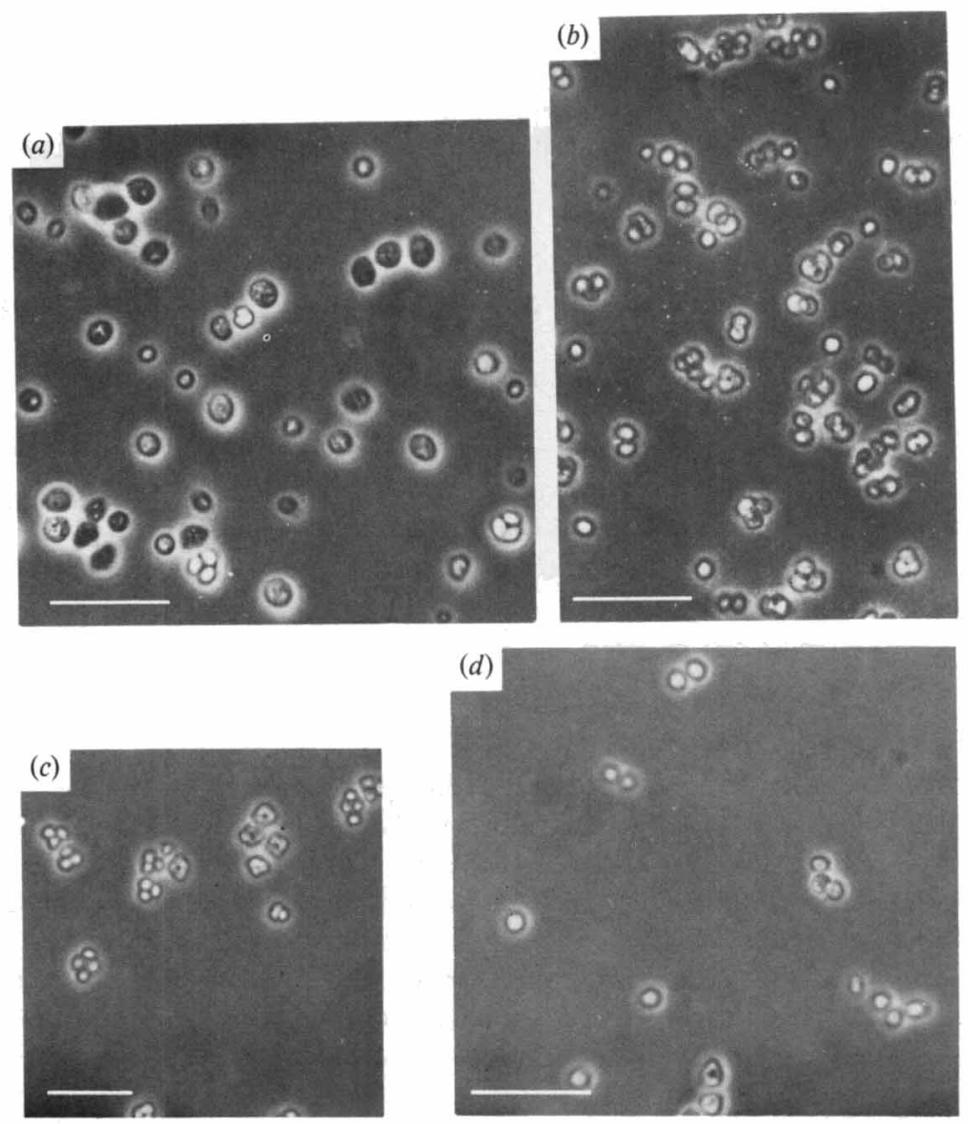

Fig. 1. Phase contrast micrographs of yeast cells. (a) Spheroplasted yeast cells forming the starting material for centrifugation. The presence of few asci can be seen. (b) The pellet after $60 \%(\mathrm{w} / \mathrm{v})$ sucrose centrifugation containing asci and vegetative cells in about $4: 1$ proportion. $(c)$ The third fraction from the top, after step gradient centrifugation, containing mainly asci. $(d)$ The bottom layer after $60 \%(w / v)$ sucrose centrifugation when treated with $5 \%(\mathrm{w} / \mathrm{v})$ Sarkosyl, liberating the ascospores from the spheroplasted asci. The spheroplasted vegetative cells were selectively ruptured in the process. The photograph shows the ascospores obtained. The bar markers represent $20 \mu \mathrm{m}$.

approach was based on two facts. First, spheroplasted vegetative cells and asci differ in size and surface properties and secondly, it was found it was possible to destroy vegetative cells in preference to the spores by lysis. The technique that was devised to fulfil our requirements is described as follows. Spheroplasts produced from cells harvested from the sporulation medium were pelleted free of enzyme and resuspended in a small volume of $1 \mathrm{M}$-sorbitol, $1.5 \mathrm{ml}$ of this suspension was layered on to $2.5 \mathrm{ml} 60 \%$ (w/v) sucrose and centrifuged at $3500 \mathrm{~g}_{\mathrm{av}}$ in a swing-out rotor for $5 \mathrm{~min}$. The upper and lower layers were carefully separated. The upper layer was free of spores while the lower layer contained $75-80 \%$ asci (Fig. $1 b$ ) and was pelleted. The pellet was suspended in a small volume of $1 \mathrm{M}$-sorbitol and charged on to a sucrose step gradient made by layering $1.5 \mathrm{ml}$ each of $65 \%, 60 \%, 55 \%$ and $50 \%$ (all w/v) sucrose solution. Gradient centrifugation was carried out at $30^{\circ} \mathrm{C}$ in a swing-out rotor at $4750 \mathrm{~g}_{\mathrm{av}}$ for $30 \mathrm{~min}$. Four clear bands were formed, and each was then carefully removed using a Pasteur pipette. The quality of asci (Fig. 1c) obtained from the third fraction from the top was by far the best and was fairly free from contamination. The mixture for step gradient centrifugation contained $77 \%$ of asci and $23 \%$ of vegetative cells. These asci distributed after centrifugation amongst the four bands from the top in the following proportion $0 \cdot 2: 28: 39: 32 \cdot 4$, each band containing varying amounts of vegetative cells. The third band containing $39 \%$ of the total asci was the purest fraction having only $1.1 \%$ vegetative cell contamination (Table 1). Evaluation of this fraction containing asci 
Table 1. Distribution and viability of cell types after spheroplasted yeast cells were centrifuged on sucrose solution

\begin{tabular}{|c|c|c|c|c|}
\hline & $\begin{array}{l}\text { Vegetative } \\
\text { cells } \\
(\%)\end{array}$ & $\begin{array}{c}\text { Asci or } \\
\text { ascospores* } \\
(\%)\end{array}$ & $\begin{array}{c}\text { Approximate } \\
\text { recovery of } \\
\text { asci/ascospores* } \\
(\%)\end{array}$ & $\begin{array}{c}\text { Viability of } \\
\text { ascospores } \\
(\%)\end{array}$ \\
\hline 1. Starting material & $95 \cdot 1$ & 4.9 & & \\
\hline $\begin{array}{l}\text { 2. Pellet from centrifugation } \\
\text { through } 60 \%(w / v) \text { sucrose } \\
\text { 3. Fractions separated on the } \\
\text { step gradient of sucrose } \\
\text { (from top downwards): }\end{array}$ & $22 \cdot 8$ & $77 \cdot 2$ & 100 & $98 \cdot 8$ \\
\hline Fraction I & $99 \cdot 2$ & $0 \cdot 8$ & $0 \cdot 2$ & $97 \cdot 4$ \\
\hline Fraction II & $39 \cdot 0$ & $61 \cdot 0$ & 28 & $98 \cdot 49$ \\
\hline Fraction III & $1 \cdot 1$ & 98.9 & 39 & $98 \cdot 23$ \\
\hline Fraction IV & $19 \cdot 7$ & $80 \cdot 3$ & $32 \cdot 4$ & $96 \cdot 89$ \\
\hline
\end{tabular}

* Observations have been tabulated on the basis that an ascus contains four ascospores.

indicated that it was completely free from any other cellular contamination. The ascospores liberated from the asci retained complete viability (Table 1). The viability of the ascospores on storage was well maintained through the use of a citrate/phosphate buffer (Rousseau \& Halvorson, 1969). These preparations were found to be suitable for use in biochemical and genetic studies. Although there was some quantitative loss of asci in the course of the procedure, the high order of purity of the preparation made up for this loss. The method was found to be reproducible and the fraction of total asci recovered in the third fraction of the step gradient was fairly consistent from one separation to another. The present technique is simple, rapid and more effective when dealing with low percentages of sporulated yeast cells than to that described by Betz \& Weiser (1976).

In cases where the loss of asci affected the suitability of the technique, an alternative protocol was adopted. The pellet, after centrifugation through $60 \%(\mathrm{w} / \mathrm{v})$ sucrose, containing chiefly asci and some vegetative cells could alternatively be suspended in $3 \mathrm{ml} 1 \mathrm{M}$-sorbitol containing $5 \%$ (w/v) Sarkosyl NL 97 (Geigy) which was then incubated at $65^{\circ} \mathrm{C}$ for $15 \mathrm{~min}$. This treatment preferentially lysed the vegetative cells, and ascospores were liberated from the asci (Fig. 1d). This method was found to be suitable for some biochemical uses, although it was not suitable for genetic studies, since Sarkosyl treatment affected the viability of the ascospores adversely. Moreover, the preparation obtained by this technique was not as free from cellular contamination as could be obtained with the step gradient procedure.

\section{REFERENCES}

Betz, H. \& Weiser, U. (1976). Protein degradation and proteinases during yeast sporulation. European Journal of Biochemistry 62, 65-76.

DaWES, I. W. \& HARDIE, I. D. (1974). Selective killing of vegetative cells in sporulated yeast culture by exposure of diethyl ether. Molecular and General Genetics 131, 281-289.

Dawes, I. W., Wright, J. F., Vezinhet, F. \& AJam, N. (1980). Separation on urografin gradients of subpopulations from sporulating Saccharomyces cerevisiae cultures. Journal of General Microbiology 119, 165-171.

Esposito, M. S. \& Esposito, R. E. (1974). Genes controlling meiosis and spore formation in yeast. Genetics 78, 215-225.

KLEIN, H. L. \& BYERS, B. (1978). Stable denaturation of chromosomal DNA from Saccharomyces cerevisiae during meiosis. Journal of Bacteriology 134, 629-635.

Nishi, K., Shimoda, C. \& Hayashibe, M. (1978). Ger- mination and outgrowth of Schizosaccharomyces pombe ascospores isolated by urografin density-gradient centrifugation. Canadian Journal of Microbiology 24, 893-897.

Padilla, G. M., Carter, B. L. A. \& Mitchison, J. M. (1975). Germination of Schizosaccharomyces pombe spores separated by zonal centrifugation. Experimental Cell Research 93, 325-330.

Piñon, R., SAlTS, Y. \& SimChen, G. (1974). Nuclear and mitochondrial DNA synthesis during yeast sporulation. Experimental Cell Research 83, 231-238.

Resnick, M. A., TIPPETIS, R. D. \& MORTIMER, R. K. (1967). Separation of spores from diploid cells of yeast by stable-flow free-boundary electrophoresis. Science 158, 803-804.

ROTH, R. \& FoGEL, S. (1971). A selective system for yeast mutants deficient in meiotic recombination. Molecular and General Genetics 112, 295-305.

Rousseau, P. \& Halvorson, H. O. (1969). Preparation 
and storage of single spores of Saccharomyces cerevisiae. Journal of Bacteriology 100, 1426-1427.

Simchen, G., Piñon, R. \& SAlts, Y. (1972). Sporulation in Saccharomyces cerevisiae. Premeiotic DNA synthesis, readiness and commitment. Experimental Cell Research 75, 207-218.

SHILO, V., SIMCHEN, G. \& SHILO, B. (1978). Initiation of meiosis in cell cycle initiation mutants of Saccharomyces cerevisiae. Experimental Cell Research 112, 241-248.

Tingle, M. A., Kuenzi, M. T. \& Halvorson, H. O. (1974). Germination of yeast spores lacking mitochondrial deoxyribonucleic acid. Journal of Bacteriology 117, 89-93. 